Marriage Conflicts Against the Psychology of Children

\title{
MARRIAGE CONFLICTS AGAINST THE PSYCHOLOGY OF CHILDREN
}

\author{
Pat Kurniati \\ Graduate Student of the Indonesian University of Education, Indonesia \\ Email: patkurnia29@gmail.com \\ Bunyamin Maftuh \\ Social Education, Indonesian University of Education, Indonesia \\ Email:bmaftuh@yahoo.co.id \\ Elly Malihah \\ Sociology Education, Indonesian University of Education, Indonesia \\ Email: ellyms@upi.edu \\ Muhamad Subkhan \\ Graduate Student of the Indonesian University of Education, Indonesia \\ Email: muhamadsubkhan212@gmail.com \\ Sri Rumiati \\ Graduate Student of the Indonesian University of Education, Indonesia \\ Email: srirumiati8@gmail.com
}

\begin{abstract}
The reality in society shows that not all married couples have the same relationship pattern. In the sense that the life forms they have to live are different from one another. There are married couples who after marriage have to live separately. On the other hand, husbands are also found in living their domestic lives in an effort to form a harmonious and happy family, always dealing with various conflicts that can affect the child's psychology. This research is a qualitative research with a descriptive approach through library research or library research that refers to sources of books, journals, and other references related to research.
\end{abstract}

Keywords: Conflict, Marriage, Psychology, Children.

\section{A. INTRODUCTION}

The ability of parents to resolve conflicts has a very important role in the child's life. Esfandyary, Baharudin, and Nowzari (2009), stated that children and adolescents are greatly affected by the condition of the relationship between their parents. If in the family there is a conflict between the two parents, then the children are like being caught 'between the parents (Sholichah, 2016). Witnessing expressions of anger and conflict can have detrimental effects for children associated with increased distress, aggression and emotional triggers, long-term adjustment problems including behavioral, emotional, social and academic problems (Cummings and Davies, in Grych \& Fincham, 2001).

Teenage Emotions One of the dimensions of human personality is the emotional dimension or the affective dimension. In everyday life, humans always have problems and try to solve the problems 
they face. Sometimes in solving the problem, they feel happy, difficult, excited, angry, or maybe worried about the situation and their role in solving the problem. In action, humans may feel excited, reluctant, lazy or worried. Whatever the situation, humans have a feeling for what they see, hear, think, and do. Therefore, a person's emotional process is not isolated from phenomena, but is a component of experiences in general that constantly affects or is influenced by other processes that take place at a certain time (Sugiyatno, 2009).

Through a psychological approach, healthy emotional attachment to parents can prevent feelings of anxiety and depression in adolescents due to the transition from childhood to adulthood. Healthy emotional attachment with parents will help adolescents to have meaningful relationships and feelings of worth (self worth) in early adulthood. From this viewpoint, it can also be explained that emotional attachment between parents and children that is built through good interpersonal communication can reduce the level of depression in children (Gunarsa, 2004).

\section{B. METHOD}

This research is a qualitative research in accordance with the object of this scientific study, so this type of research is included in the category of library research. The research was conducted by examining and interpreting theoretical matters relating to the discussion. This study aims to determine how the form of conflict resolution in terms of its effect on children's psychology in married couples. The method used to explain this research is descriptive method.

In its implementation, this research goes through several participant observation steps, namely in this observation activity the writer pays attention to four things, namely observations with serious planning, focus on research objectives, recording systematically and linked to general propositions, and the validity level can be checked and controlled 2007). According to Bogdan and Taylor (1975), participatory observation is used in research which is characterized by a period of intensive social interaction between the researcher and the subject in a community environment. During this participatory observation period, data were collected in a careful and systematic manner. To obtain data through participatory observation, the researcher tries to intensively follow the character's activities.

Data analysis includes activities to organize, sort, classify, code / sign, and categorize data so that work hypotheses can be found and formulated based on these data (Moleong, 1995). Data analysis is useful for reducing data sets to embodiments that can be understood through logical and systematic descriptions so that the focus of the study can be examined, tested, and answered carefully and thoroughly (Moloeong, 1995).

The steps that will be taken in the data processing process are as follows:

1. Categorization, namely collecting data based on certain categories (such as: documentation, history, socio-culture, politics, education, etc.)

2. Typologization, namely grouping data based on certain patterns based on opinions, thoughts, and certain criteria (such as traditional, modern, etc.).

3. Editing data, which is useful for correcting and rechecking the data that has been collected so that there are no errors and overlapping discussions. Meanwhile, the data analysis used in this research is descriptive analysis. In this case, the data display results from the exposures of the research subjects obtained from the decomentation study. From the 
results of these descriptive data, then analyzed with the aim of finding a more complete and comprehensive understanding.

It should be remembered by researchers that the large amount of data obtained in the field does not guarantee the importance of a study. The data only gives important meaning if the researcher is able to carry out a good analysis so that the results meet scientific principles and can be accepted by many people (Furchan and Maimun, 2005).

\section{RESULT AND DISCUSSION}

\section{Literature review}

Sadarjoen (2005) states that marital conflict is a conflict involving a husband and wife partner where the conflict has a significant effect or influence on the relationship between the two partners. This conflict arises because of different perceptions, expectations and is supported by their existing backgrounds, needs and values before deciding to form a marriage bond (Dewi and Basti, 2008).

Conflict has various kinds of elements, including that conflict has negative and positive effects, conflict can focus on the content of the conversation or the material of the problem, but conflict can also be related to the person of the perpetrator. Conflict has several forms or styles and conflict is also determined by cultural factors (DeVitto: 2007). So that discussions about conflict can be viewed from various aspects and what is more interesting is knowing the impact of the conflict and linking it to the causes of conflict. Conflict itself cannot be avoided when one is in contact with other people. Even conflicts can occur with individuals without involving other people. Related to the broad and integrated understanding of conflict, both De Vitto (2007) and Galvin and Brommel (1986) both provide descriptions of the stages of conflict occurring to how to manage conflict. It is stated that conflict has several stages of the process, namely the initial condition stage, the frustration and awareness stage, the active stage, the solution stage or the solution is not reached, the follow-up stage and the resolution stage.

According to Gottman (1994) in a marriage, individuals face a number of marital issues that can lead to conflict. Married couples will be faced with various simple and complex problems that can trigger conflict. Although conflict and tension do not always indicate instability in a marriage, many couples only face it as a problem (James \& Wilson, 2002). Gottman (1994) argues that some married couples perceive conflict as a minor disturbance in the marriage, but for others it can be more complex and occur more frequently. If someone often feels disturbed due to the conflict they experience, or feels that they have a distance from their partner, then the conflict can be a warning or a threat to the individual's relationship with his partner (Murdiana, 2015).

Conflicts that occur in a marriage cannot be allowed to continue, there must be efforts to overcome the conflicts that occur so that the negative impacts caused by the occurrence of conflicts can be avoided. Conflicts that are not resolved properly will have a negative impact on married life and also have long-term impacts on other family members. Therefore, the pattern of resolving marital conflicts needs to be studied further. Hocker \& Wilmott in Lim (2000) define marital conflict

resolution as a collection of responses or a number of behaviors used by individuals when facing conflicts with their partners.

According to Piaget's cognitive development (in Santrock, 2003), children / adolescents reach the stage of formal operational thinking, which is a stage of cognitive development that takes place at 
the age of 11-15 years. At the stage of formal operational thinking, a child / adolescent is able to think more abstractly, idealistically and more logically than the thinking of a child. Apart from being abstract, children / adolescents begin to think about ideal characteristics for themselves and others by comparing themselves and others with their ideal standards. In addition, adolescents also begin to think more logically (Kuhn in Santrock, 2003) like scientists, who devise plans to solve problems and test problem solving systematically (trial and error). So that at this time, a child / adolescent likes to try something or new situation.

Moral development is related to rules and values regarding what a person should do in his interactions with others (Santrock, 2003), which includes how children / adolescents consider rules to conduct ethical behavior; how the child / adolescent behaves in actual situations and how the child / adolescent feels calm moral problems. Moral reasoning of children / adolescents is one of the important needs as a guideline for finding their own identity, developing harmonious personal relationships and avoiding role conflicts that occur during transitional periods (Kohlberg, in Desmita, 2013). People who act in accordance with morals are people who base their actions on judgments of whether something is good or bad.

During the period of moral development, children / adolescents have the urge to do actions that can be considered good by others. Children / adolescents behave not only to fulfill their physical satisfaction but also psychologically such as feeling satisfied with the acceptance and positive assessment of others regarding their actions. In the stages of moral development in Kohlberg (in Desmita, 2013), the level of adolescent moral reasoning at the conventional stage where an action is considered good by adolescents if they comply with the expectations of the authority or peer group (Chusniyah, 2015).

\section{Conflict Marriage}

Several studies of marriage therapists who work with multiple partners (in Kerr et al, 2003) identify the problems most commonly reported by couples. The results of these studies indicate that poor communication, power struggles, unrealistic expectations about marriage, sexual relationship problems, and difficulties in making early decisions, are things that can lead to divorce in married couples (Huff et. Al 2003). Divorce itself has a significant impact, both on the lives of the couple and on their children. Some researchers agree that children from divorced families show poorer adjustment than children from non-divorced families (Wahyuti and Syarief, 2016). Another factor that determines the success of children in the future is the stages of growth and development they are going through. Each individual goes through various stages of development during the course of his life, the individual will also experience a growth process (Florsheim, 2006).

Growth and development are important aspects that must be passed through by individuals well. According to Englund et. al (2004) growth and development are both a process of change that leads in a certain direction; but there are also those who differentiate even though it is actually difficult to separate. During the stages of development and growth, at some point children begin to learn and understand a new experience from various aspects of life such as social skills, emotional regulation, cognitive abilities, and moral values (Dinh et. Al, 2002). The good and bad development that a child goes through will certainly affect all aspects of a child's life, one of which is selfconcept. Dinh and Nguyen (2006) explain self-concept as the idea of oneself which includes one's beliefs, views, and judgments about oneself. The self-concept consists of how a person sees 
himself as a person, how a person feels about himself, and how a person wants himself to be the human being that person expects (Davalos et. Al, 2005).

Disputes, contradictions and conflicts in a household are something that sometimes cannot be avoided, but must be dealt with. This is because in a marriage there is a union of two unique persons by bringing their respective belief systems based on different cultural backgrounds and experiences. The differences that exist need to be adjusted with each other to form a new belief system for their family. This process often creates tension, coupled with a number of changes they have to face, for example changes in living conditions, changes in habits or changes in social activities (Dewi and Basti, 2008).

McGonagle et al in Sears et al (1994) stated that in married couples, conflict is a common condition. This is in accordance with the research conducted by Gurin et al in Sears et al. (1994), which concluded that conflict will always occur in married life. This is shown by the results of their research where $45 \%$ of married people said that in life together various problems will always arise, and $32 \%$ of couples who rated their marriage as very happy reported that they had also experienced conflicts.

Coser in Anogara (1992) states that conflict always exists in the place of life together, even in perfect relationships, even though conflict is inevitable and conflicts increase in serious relationships. Any time when there are two people or two groups who will make a decision has the potential to cause a conflict. The source of conflict can come from contact interactions when two competing parties or one party tries to exploit the other party (Brigham, 1991).

Life in a marital bond will always be faced with various kinds of problems and require maturity from the husband and wife to solve these problems. In solving problems, it is often found that married couples are involved in disputes and even quarrels because they are based on differences in opinions and views in seeing the problems at hand. This condition then resulted in new conflict resolution from both parties, and this condition will continue. When conflict resolution, of course, consists of changes, whether it is changing the values that they each have embraced or changing their habits, they do not agree, it will lead to new conflicts again (Dewi and Basti, 2008).

\section{Discussion}

There are at least four ways couples can resolve conflicts in marriage, namely avoiding conflict, giving in, discussion, and competence. Conflict avoidance is done where the couple raises behavior that can prevent them from continuing conflict, by diverting the conversation from the issue being discussed. Giving in is done by one partner giving in to his partner without resolving the conflict. Discussions were held with the aim of finding alternatives that best satisfy the aspirations of both parties. One partner's competence will try to make his opinion used in resolving the conflict. In competence, one partner finds fault or blames the partner, or it can also be by persuading / seducing the partner even by forcing it directly, so that in the end the partner will give in.

In processing her life, women always associate thoughts and problems with other thoughts and problems in a certain way. This makes women try to link life together. They solve problems from a point of view that is different from the perspective of men. For most women, rushing to solve a problem that includes many unrelated things is an act of denial. Women consistently feel the need 
to talk things over thoroughly. In conversation, women can relate logical, emotional, relational, and spiritual aspects of a topic.

Conflict resolution between partners in their marriage is one of the most important factors in determining the welfare of the relationship. Conflict resolution is indeed related to the psychology of children and is an important part of achieving the psychological well-being of partners in married life. The ability of a couple to face conflict and resolve it is also influenced by their perception of the marriage that is built. Whatever conflict resolution style and technique is chosen, it is necessary to consider its effectiveness in achieving marital harmony. In addition, the partner's willingness to seek appropriate conflict resolution efforts is also one of the considerations in achieving a happy marriage. Marriage satisfaction is an aspect of the quality of marriage that plays an important role in domestic life. It cannot be denied that marital satisfaction arises along with the need to identify a partner's character, communication patterns and adaptive behavior. What's more, marriage satisfaction has been proven to be effective in causing improvements in all aspects of life, including family function, parenthood, health to life satisfaction. Thus, marital satisfaction is an essential factor in the mental health of individuals and families.

For couples, positive actions that can be taken to resolve conflicts in the household are by communicating or discussing to solve problems together with a partner. With this, the most suitable conflict resolution style to use is the collaborative style in which individuals will be more open, and can discuss decisions with their partners about decisions that can be taken to resolve conflicts, this will make the couple feel more valued in their marriage and will create a positive situation. in the household (Saputri, 2020).

In the process of realizing children's self-actualization, the role of the family, especially parents, is very important. The family is the first social group in human life where he learns and states himself as a social human being, in interaction with his group (Ahmadi, 2007). The position of the relationship between parents and children can be explained by the theory of family relationship schemas. This theory explains the interaction of a person with other family members at a certain time. The family relationship scheme theory classifies families into categories that can make it easier for researchers to be able to find out the communication patterns used by the family (Santosa, 2019). Basically, communication within a family is the most important thing because it determines the changes in the shape of a family. This change highlights communication as the most effective mechanism for determining family roles, rules, and systems that apply in a family (Le Poire, 2006).

\section{CONCLUSION}

Couples can resolve conflicts in marriage, namely avoiding conflict, giving in, discussion, and competence. Conflict avoidance is done where the couple raises behavior that can prevent them from continuing conflict, by diverting the conversation from the issue being discussed. Giving in is done by one partner giving in to his partner without resolving the conflict. Discussions were held with the aim of finding alternatives that best satisfy the aspirations of both parties. One partner's competence will try to make his opinion used in resolving the conflict. So that the resolution of conflicts in marriage will have a good effect on the psychology of children. On the other hand, continuous conflict will have a bad influence on children's psychology. 


\section{REFERENCES}

Ahmadi, Abu. 2007. Psikologi Sosial. Jakarta: Rineka Cipta.

Anogara. (1992). Psikologi kerja. Jakarta: Rineka Cipta.

Bogdan, R., and Taylor, S.J. (1975). Introduction to Qualitative Research Methods: A Phenomenological Approach to the Social Sciences. New York: Wiley.

Brigham, J.C. 1991 Social psychology second edition New York: Harpercollins Publisher Inc.

Brommel, Bernadr J \& Galvin, Kathleen M. (1986). Family Communication, Cohesion and Change. US: Foresman \& Company.

Bungin, B. (2007). Penelitian Kualitatif : Komunikasi, Ekonomi, Kebijakan Publik Dan IImu Sosial Lainnya. Jakarta : Kencana.

Chusniyah,T. (2015). Problem dalam Perkembangan Psikologi Anak yang Berhadapan dengan Hukum. Fakultas Pendidikan Psikologi Universitas Negeri Malang.

Davalos, D. B., Chavez, E. L., \& Guardiola, R. J. (2005). Effects of perceived parental school support and family communication on delinquent behaviors in Latinos and White nonLatinos. Cultural Diversity and Ethnic Minority Psychology, 11, 57-68.

Desmita. (2013). Psikologi Perkembangan. Bandung: PT. Remaja Rosdakarya.

DeVito, J. (2007). The Interpersonal Communications Book. USA: Pearson Education.

Dewi, E M P dan Basti. (2008). Konflik Perkawinan dan Model Penyelesaian Konflik pada Pasangan Suami Istri, Jurnal Psikologi, Vol. 2, No. 1, Desember 2008. $42-51$.

Dinh, K. T., \& Nguyen, H. H. (2006). The effects of acculturative variables on Asian- American parent-child relationships. Journal of Social and Personal Relationships, 23, 407-426.

Dinh, K. T., Roosa, M. W., Tein J.Y., \& Lopez, V. A. (2002). The relationship between acculturation and problem behavior proneness in a Hispanic youth sample: A longitudinal mediational model. Journal of Abnormal Psychology, 30, 295-309.

Englund, M. M., Luckner, A. E., Whaley, G. L., \& Egeland, B. (2004). Children's achievement in early elementary school: Longitudinal effects of parental involvement, expectations, and quality of assistance. Journal of Educational Psychology, 96, 723-730.

Esfandyary, B., Baharudin, R., dan Nowzari, L., (2009). The Relationship between Inter-parental Conflict and Externalizing Behavior Problems among Adolescents, European Journal of Social Sciences, 12, (1), 11-122

Florsheim, P., Tolan, P., \& Gorman-Smith, D. (2006). Family relationships, parenting prac- tices, the availability of male family members, and the behavior of inner-city boys in sin- glemother and two-parent families. Child Development, 69, 1437-1447.

Furchan, A dan Maimun, A. (2005). Metode Penelitian. Yogyakarta: Pustaka Pelajar.

Gottman. John M. (1994). The Seven Principle for Making Marriage Work. New York. Crown Publishers, Inc. 
Grych, J.H dan Fincham,F.D., (2001), Interparental conflict and child development: theory, research and applications, New York: Cambridge University Press.

Gunarsa, Singgih D. (2004). Bunga Rampai Psikologi Perkembangan: Dari Anak Sampai Usia Lanjut. Jakarta: BPK.

Huff, C., Widner, M., \& McCoy, K. (2003). The influence of challenging outdoor recreation on parent-adolescent communication. Therapeutic Recreation Journal, 37, 18-37.

James, Adrian L, \& Wilson, Kate. (2002). Couple, Conflict, and Change: social work. London. The Taylor \& France e-Library.

Kerr, M. H., Beck, K., Shattuck, T. D., Kattar, C., \& Uriburi, D. (2003). Family involvement, problem and prosocial behavior outcomes of Latino youth. American Journal of Health Behavior, $27,55-65$.

LePoire, Beth A. 2006. Family Communication ; Nurturing and Control in a Changing World. United State of America: Sage Publication.

Lim, Ben K H. (2000). Conflict Resolution Styles, Somatization, and Marital Satisfaction in Chinese Couple: Moderating Effect of Forgiveness and Willingness to Seek Profesional Help. Disertation. Texas. Texas tech University.

Moleong, L J. (1995). Metodelogi Penelitian Kualitatif. Bandung: Rosda Karya.

Murdiana, S. (2015). Penyelesaian Konflik Perkawinan Ditinjau dari Usia Perkawinan, Indonesan Journal of Applied Sciences Vol. 5 Nomor 3 Edisi Desember 2015, 135-142.

Sholichah, M. (2016). Pengaruh Persepsi Remaja Tentang Konflik Antar Orang Tua dan Resiliensi Terhadap Depresi dan Kecemasan. Jurnal Humanitas Vol. 13 No. 1 . 22-36

Santosa, M A. (2019). Komunikasi Antar Pribadi Orangtua dan Anak dalam Proses Pengembangan Bakat Dan Pemilihan Karir Anak dengan Pilihan Profesi Musisi. Vol 7, No 3: Agustus 2019.

Santrock, J.W. (2003). Life-Span Development. Perkembangan Masa Hidup. Edisi Kelima. Jilid 2. Alih Bahasa: Damanik, J., dan Chusairi, A. Jakarta: Erlangga.

Saputri, S A. (2020). Gaya Resolusi Konflik dan Kepuasan Pernikahan pada Wanita yang Menikah Muda. Jurnal Imiah Psikologi PSIKOBORNEO Vol. 8 No. 3, June 2020: 361-374.

Sugiyatno. (2009). Strategi Menghadapi Konflik Emosional Orang Tua-Remaja, Jurnal Paradigma, No. 08 Th. IV, Juli 2009.

Wahyuti, T dan Syarief, L K. (2016). Korelasi Antara Keakraban Anak dan Orang Tua Dengan Hubungan Sosial Asosiatif Melalui Komunikasi Antar Pribadi. Jurnal Visi Komunikasi/Volume 15, No.01 2016. 143-157. 